\title{
De digitale schandpaal: opsporingsberichtgeving in een gedigitaliseerde samenleving ${ }^{*}$
}

\author{
Gabry Vanderveen \& Mojan Samadi
}

De digitalisering van de samenleving heeft geleid tot meer burgerparticipatie bij de opsporing. De dilemma's waar het Openbaar Ministerie (OM) zich voor gesteld ziet bij de inzet van opsporingsberichtgeving, effectieve opsporing versus respect voor de persoonlijke levenssfeer, zijn door internet en sociale media indringender dan vroeger. Wanneer een opsporingsbericht eenmaal naar buiten is gebracht, is verdere verspreiding daarvan onbeheersbaar. Resulterend in grote inbreuken op de privacy van de verdachte waar de strafrechter rekening mee kan houden. Drie zaken illustreren de kenmerken van opsporingsberichtgeving in een gedigitaliseerde samenleving en de juridische consequenties daarbij en onderstrepen de noodzaak tot een maatschappelijke discussie hierover.

\section{Inleiding}

'Nu kan ik niet geloven dat dit het enige is wat de politie voor me kan betekenen. Zeker niet in een wereld vol met social media en Opsporing Verzocht. Vandaar dat ik het dus nog een keer aan jullie wil vragen of jullie mijn bericht zo vaak mogelijk willen delen om misschien wel bij een dader uit te komen, maar ook om zo veel mogelijk aandacht te krijgen voor dit soort enorme missers van onze overheid.' (citaat uit Facebookbericht geplaatst op 1 augustus 2017)

Bovenstaand citaat is geplaatst door de eigenaar van een motor die gestolen is. De eigenaar heeft dit gemeld bij de politie en er blijken camerabeelden te zijn waarop de verdachte met de motor te zien is. Deze beelden worden niet in de vorm van opsporingsberichtgeving verspreid, reden voor de eigenaar een oproep te plaatsen op Facebook en zijn verhaal te doen in het Leidsch Dagblad (Van Aarsen, 2017):

'Te klein voor Opsporing Verzocht, zeggen ze. Als ik vraag om de beelden of als ik vraag waar de motor voor het laatst gezien is, zeggen ze dat ze geen informatie kunnen geven. Privacy van de meneer op de motor. Het moet niet gekker worden.'

In De Telegraaf - die dit bericht heeft opgepikt - komt een woordvoerder van de politie aan het woord. Deze legt uit dat de Aanwijzing Opsporingsberichtgeving van het OM bepaalt hoe het werk 'in dit soort zaken' gedaan moet worden: 'Daar staat in dat er ook zoiets is als privacy van verdachten. Dat dienen we te respecte-

* $\quad$ Dit stuk is deels gebaseerd op Vanderveen en Oerlemans (2017). 
ren' (Kalkman, 2017). In dit geval heeft het OM na een belangenafweging besloten geen opsporingsberichtgeving in te zetten. De oproep van het slachtoffer, alsmede deze reactie van de politie zorgen echter voor veel verontwaardiging op sociale media en worden breed uitgemeten op verschillende (nieuws)sites, waardoor de beelden alsnog in de openbaarheid komen.

Dit voorbeeld laat zien hoe de digitalisering van de samenleving heeft geleid tot meer participatie van burgers bij de opsporing, wat grote gevolgen heeft voor de inzet van opsporingsberichtgeving door het OM. Het voorbeeld schetst hiermee een belangrijk dilemma waar het OM zich voor gesteld ziet: simpelweg weigeren beelden van strafbare feiten te delen is niet altijd mogelijk, omdat burgers het heft in eigen handen kunnen (en/of zullen) nemen, terwijl zelf delen van die beelden evenmin opportuun kan zijn, gezien de inbreuk op de privacy van de (verdachte) burger, vooral daar waar de ernst van het strafbare feit gering is. Door de digitalisering van de samenleving zijn deze dilemma's mogelijk nog indringender dan vroeger. Het medialandschap waarin opsporingsberichtgeving zich beweegt, is dankzij internet en diverse sociale media drastisch veranderd. Het speelveld van de publieke opinievorming is daarmee onvoorspelbaar en onoverzichtelijk geworden (RMO, 2011).

Burgerparticipatie in de opsporing wordt door velen ook als een welkom verschijnsel gezien. Kop (2016) pleit voor wat zij DIY (Do-It-Yourself)-policing noemt. Zij schetst de kansen voor politie en $\mathrm{OM}$ om de burger meer bij de opsporing te betrekken. Immers, informatie van burgers, bijvoorbeeld als getuige of slachtoffer, is voor de opsporing van oudsher essentieel. Het klassieke buurtonderzoek, waarbij de politie rondvraagt bij bewoners van een buurt waar een (ernstig) delict is gepleegd, is in de loop van de tijd uitgebreid met bijvoorbeeld het televisieprogramma Opsporing Verzocht, Burgernet, Amber Alert, en verschillende apps (zoals de politie-app Samen Zoeken en Sherlock) waarbij de politie de burger betrekt bij de opsporing (Kop, 2013; Van Laarhoven, 2018; TNO, 2018). Ook op populaire sociale mediaplatforms als Facebook en Twitter plaatst de politie oproepen om informatie te delen en te vragen. De digitalisering leidt zo tot meer burgerparticipatie: burgers en politie coproduceren samen veiligheid (Meijer, 2014). Nadelen aan deze vorm van burgerparticipatie bij de opsporing signaleert Kop (2013) ook, bijvoorbeeld wanneer (vermeende) verdachten aan de digitale schandpaal genageld worden, zoals in de Eindhovense zaak waar we nog op terug zullen komen. Wijkhuis en De Vries (2014) concluderen dat door sociale media burgervervolging dichterbij lijkt te komen. Online eigenrichting (vigilantism), ook wel digilantism genoemd, kan leiden tot gevaarlijke situaties en tot misidentificatie van onschuldige burgers als daders (Nhan, Huey \& Broll, 2017). Bovendien brengt deze praktijk ook grote risico's met zich voor de privacy: de burger is niet altijd in staat een gewogen oordeel te vellen over het al dan niet delen van dergelijke berichten, waardoor deze gevolgen niet te voorzien zijn (o.a. Moerman, 2016).

De bovengenoemde nadelen gelden ook wanneer de hulp van de burger bij de opsporing wordt ingeroepen door het OM, bijvoorbeeld door de verspreiding van opsporingsberichtgeving. Veel meer dan vroeger kan dit grote gevolgen hebben voor de (privacy van de) verdachte. Burgers en bedrijven kunnen deze beelden 
immers makkelijker verder verspreiden via sociale mediakanalen en websites als Geenstijl. In dit kader is ook het wetsvoorstel 'publicatie camerabeelden verdachten diefstal of vernieling' noemenswaardig (Ministerie van Justitie en Veiligheid, 2015). Met deze wet wil de wetgever het eenieder mogelijk maken om camerabeelden van diefstal, inbraak en vernieling te delen (op het internet). Dit is ingegeven vanuit de behoefte om meer en beter gebruik te maken van technologische ontwikkelingen en burgers meer te betrekken bij de opsporing. Volgens de minister is de uitdrukkelijke wens om meer betrokken te zijn bij het veiligheidsvraagstuk duidelijk aanwezig in de huidige samenleving (Kamerstukken II, 2013/14, 29628, nr. 464, p. 25). Het behoeft weinig betoog dat dit risico's voor de privacy van burgers met zich brengt. Deze relatief recente ontwikkeling en de inzet van opsporingsberichtgeving in de huidige samenleving in het algemeen verdient een bredere maatschappelijke discussie, waar wij met dit artikel aan willen bijdragen. In deze bijdrage gaan wij in op de verantwoordelijkheid van het OM in het licht van de vergaande gevolgen die het verspreiden van opsporingsberichtgeving kan hebben in een tijd dat internet en sociale media niet meer weg te denken zijn. Hierbij zullen we eerst stilstaan bij normering van de inzet van opsporingsberichtgeving, namelijk het juridisch kader van het OM waar de officier van justitie aan gehouden is bij de beslissing om al dan niet gebruik te maken van opsporingsberichtgeving (par. 2). Vervolgens gaan we in op de veranderingen die digitalisering met zich brengt voor opsporingsberichtgeving. Door de digitalisering is een strikt onderscheid tussen verschillende soorten media niet meer mogelijk. Bovendien faciliteert digitalisering (een vergaande vorm van) burgerparticipatie in de opsporing, doordat zij burgers in staat stelt privacygevoelige informatie (verder) te verspreiden. Dit kan massale media-aandacht genereren met alle gevolgen van dien. Aan de hand van drie zaken bespreken we de gevolgen van de inzet van opsporingsberichtgeving in de huidige gedigitaliseerde samenleving (par. 3 en 4). Tot slot zal in de laatste paragraaf aandacht worden besteed aan de gevolgen van de uitvaardiging van opsporingsberichtgeving voor het strafproces (par. 5). Hierbij wordt stilgestaan bij de wijze waarop opsporingsberichtgeving is ingezet in de zogenoemde Kopschopperszaak en de zaak Juwelier Stratmann. In beide zaken dwong de inzet van opsporingsberichtgeving de rechter ertoe zich te buigen over de vraag in hoeverre deze inbreuken op de rechten van de verdachte gepaard dienen te gaan met rechtsgevolgen op grond van artikel 8 EVRM en artikel 359a Wetboek van Strafvordering. ${ }^{1}$ Ook hebben beide zaken geleid tot maatschappelijke discussies over het privacybelang en het opsporingsbelang en de balans daartussen.

1 Art. 8 Europees Verdrag voor de Rechten van de Mens (EVRM) betreft het recht op eerbiediging van privé-, familie- en gezinsleven; art. 359a Wetboek van Strafvordering (Sv) vormt de wettelijke grondslag voor de rechter om rechtsgevolgen (niet-ontvankelijkheid OM, bewijsuitsluiting en strafvermindering) te verbinden aan vormverzuimen begaan in het vooronderzoek. 


\section{De normering van de inzet van opsporingsberichtgeving: de Aanwijzing Opsporingsberichtgeving}

In de oude Aanwijzing van het OM werd opsporingsberichtgeving gedefinieerd als een 'opsporingsmiddel in strafvorderlijke zin waarbij de hulp van het publiek wordt ingeroepen via de media en andere openbare berichten, om voor het opsporingsonderzoek relevante informatie te verkrijgen' (Aanwijzing Opsporingsberichtgeving (2009A004). Deze Aanwijzing is per 1 december 2017 vervangen door de nieuwe Aanwijzing Opsporingsberichtgeving, die een aanzienlijk ruimere definitie geeft aan dit 'opsporingsmiddel'. Volgens deze nieuwe aanwijzing kan opsporingsberichtgeving, naast voor opsporingsdoeleinden, ook worden ingezet om hulp te vragen van het publiek bij waarheidsvinding (te denken valt aan getuigenen slachtofferoproep), de tenuitvoerlegging van rechterlijke beslissingen (het vinden van veroordeelden die hun straf nog moeten uitzitten), of het voorkomen van strafbare feiten. Kortom, de opsporingsberichtgeving wordt niet langer enkel ingezet voor de opsporing van strafbare feiten, maar kan tevens worden gebruikt ter verwezenlijking van de hiervoor genoemde (zeer ruim geformuleerde) doeleinden. De hoofdofficier van justitie en landelijk portefeuillehouder opsporingsberichtgeving Diederik Greive stelt in een interview met De Telegraaf dat deze verruiming noodzakelijk was om 'effectiever' te worden en 'nog meer zaken te kunnen oplossen'. Hij voegt daaraan toe dat nieuwe technologische ontwikkelingen ertoe hebben bijgedragen dat het OM steeds meer scherper beeldmateriaal heeft: 'Die willen we kunnen gebruiken, zonder de privacybelangen van met name slachtoffers uit het oog te verliezen' (in: Van Wely, 2017). Naast privacybelangen van slachtoffers laat de hoofdofficier van justitie zich ook uit over de verdachte burger:

'We zetten al jaren opsporingsberichtgeving in als instrument. Het OM is erg zorgvuldig. De inzet leidt niet vaak tot een klacht. En bovendien: criminelen die "on the run" zijn, gaan ons niet bellen met een klacht.'

In het hiernavolgende zullen we ons richten op de gevolgen van opsporingsberichtgeving die ten behoeve van de opsporing is uitgevaardigd en laten daarbij de andere doeleinden waarmee deze berichtgeving sinds kort ook uitgevaardigd kan worden buiten beschouwing.

Het gebruik van de media door de politie en het OM bij de opsporing van strafbare feiten is allerminst een nieuw fenomeen. Geïnspireerd door het Duitse voorbeeld wordt al sinds de jaren zeventig gebruikgemaakt van televisie om het politiespeurwerk verder te helpen (Werkgroep opsporingsberichtgeving per televisie, 1971). Het bekendste voorbeeld hiervan is het televisieprogramma Opsporing Verzocht, dat na proefuitzendingen in 1975 en 1976 sinds 1982 gebruikt wordt als middel om hulp van burgers te krijgen bij de opsporing (Van Erp, Van Gastel \& Webbink, 2012). Dankzij Opsporing Verzocht worden zaken opgelost die anders níet zouden zijn opgelost (Webbink, Van Erp \& Van Gastel, 2017). Ondanks het inmiddels lange bestaan van dit opsporingsmiddel, heeft het in het Wetboek van 
Strafvordering (hierna: Sv) geen uitdrukkelijke wettelijke grondslag. De bevoegdheid dit middel in te zetten wordt gevonden in de algemene bepaling van artikel 141 Sv. ${ }^{2}$ Opsporingsactiviteiten die hun grondslag vinden in artikel 141 Sv worden doorgaans als weinig problematisch gezien, omdat hiermee geen (grote) inbreuken worden gemaakt op de rechten van (verdachte) burgers. Dat wil echter niet zeggen dat zij geheel ongenormeerd zijn. Ook de inzet van opsporingsberichtgeving is nader genormeerd (in lagere regelgeving), aangezien het gebruik van deze opsporingsmethode inbreuk kan maken op het recht op privacy van de verdachte. De Aanwijzing opsporingsberichtgeving geeft de kaders aan voor de inzet van dit opsporingsmiddel. De nieuwe Aanwijzing verruimt als gezegd niet alleen de mogelijkheden om verdachten op te sporen, maar ook om getuigen en slachtoffers te vinden: ook zij kunnen herkenbaar in beeld komen. Ook dan zal het $\mathrm{OM}$ een belangenafweging moeten maken, waarbij het opsporingsbelang doorslaggevend kan zijn:

'Het kan heel goed dat we mensen bijvoorbeeld in eerste instantie altijd blurren, omdat het om een getuige gaat. De kans bestaat ook dat het daar bij blijft. Maar als het opsporingsbelang zwaarder weegt, dan kun je daar van afwijken en iemand herkenbaar afbeelden. Tenzij iemand gevaar loopt natuurlijk, dan moeten we het gewoon niet doen.' (Officier Ernst Pols, landelijk portefeuillehouder opsporingsberichtgeving, in: Klomp, 2017)

Opsporingsberichtgeving kan dus de persoonlijke levenssfeer of andere belangen van betrokkenen raken (verdachte, slachtoffer, getuigen). Het is daarom van belang dat het OM bij de beslissing om dit middel in te zetten zich rekenschap geeft van de belangen van alle betrokken personen. In de Aanwijzing wordt hieromtrent opgemerkt dat bij de uitvaardiging van opsporingsberichtgeving het OM in het licht van artikel 8 EVRM een zorgvuldige belangenafweging zal maken, waarbij de vereisten van rechtmatigheid, proportionaliteit, subsidiariteit, en doelmatigheid leidend zullen zijn (Aanwijzing Opsporingsberichtgeving, 2017A 007). Concreet betekent dat dat het OM steeds voor ogen moet houden dat de zwaarte van het in te zetten middel in verhouding staat tot het beoogde doel en dat de ernst van het feit de inbreuk op de privacy van de verdachte (en andere betrokkenen) rechtvaardigt. Hoe ernstiger het gepleegde delict is, hoe zwaarder het opsporingsbelang zal wegen. Daarnaast dient het minst zware middel ingezet te worden: wanneer het doel met een voor de verdachte minder belastend middel kan worden bereikt, moet voor dat middel worden gekozen. In de Aanwijzing wordt tot slot ook stilgestaan bij het maatschappelijk gebruik van internet en sociale media bij het verspreiden van opsporingsberichtgeving. Uitgangspunt is dat de toegang vanuit het openbaar domein tot het tekst- en beeldmateriaal van het opsporingsbericht in beheer bij politie of OM wordt geblokkeerd, zodra de noodzaak voor de inzet van het middel is komen te vervallen. Maar de verspreide informatie zal doorgaans in het 'permanente digitale geheugen' terechtkomen.

2 Art. $141 \mathrm{~Sv}$ wijst de actoren aan die belast zijn met de opsporing van strafbare feiten (de officier van justitie en andere opsporingsambtenaren). 
Verdere verspreiding door derden van een opsporingsbericht via internet of sociale media en toevoeging van kwalificaties aan of manipulaties van het primair verspreide beeld komen steeds vaker voor. Dit gegeven noopt tot een zorgvuldige afweging bij de keuze voor de tekst, het eventuele beeldmateriaal en het medium (Aanwijzing Opsporingsberichtgeving 2017A007).

Anders dan in de vorige Aanwijzing kan de politie ook zonder toestemming van het OM beeldmateriaal verspreiden (mits de beelden niet herleidbaar zijn tot personen). En hoewel de hoofdofficier van justitie verantwoordelijk blijft voor de inzet van opsporingsberichtgeving, kan hij de uitvoering van (een deel van) deze taak beleggen bij de persofficier van justitie of de rechercheofficier van justitie. Daarnaast worden ook de regionale en landelijke overlegorganen die adviseren over de consequenties en de rechtmatigheid en noodzakelijkheid van de inzet van opsporingsberichtgeving (art. 7 Aanwijzing Opsporingsberichtgeving 2009A004)) niet langer genoemd in de nieuwe Aanwijzing. De Aanwijzing stelt slechts dat de uitvaardiging van opsporingsberichtgeving plaatsvindt onder het gezag van de officier van justitie, waarmee overigens slechts de systematiek van het Wetboek van Strafvordering wordt onderschreven (art. 132a Sv).

Het uitvaardigen van opsporingsberichtgeving raakt ook aan de voorlichtingsrol van het OM inzake strafzaken. De Aanwijzing Voorlichting opsporing en vervolging (2012A009) stelt dat deze voorlichtingstaak van het OM voortvloeit uit de taakstelling van politie en OM, namelijk het leveren van een effectieve bijdrage aan een veilige en rechtvaardige samenleving. Volgens het OM vereist deze taak mede dat justitiële interventies 'zichtbaar, merkbaar en herkenbaar zijn voor slachtoffers, daders en hun omgeving, en dat OM en politie open zijn over hun afwegingen en fouten' (Aanwijzing voorlichting opsporing en vervolging). Transparantie over de wijze waarop criminaliteit wordt aangepakt (zowel op beleidsniveau als in concrete zaken) draagt volgens het $\mathrm{OM}$ bij aan het vertrouwen van de burger in de rechtsstaat en de legitimiteit van het OM en de politie, vandaar dat het OM een proactief communicatiebeleid voert (zie uitgebreid Van Lent, 2008: 111-115). Het is hierbij vanzelfsprekend dat niet over elke strafzaak actief aan voorlichting zal worden gedaan, maar het zal niet verbazen dat geruchtmakende zaken die al in het nieuws zijn geweest (bijvoorbeeld vanwege de inzet van opsporingsberichtgeving) nopen tot nadere informatie vanuit het OM. De inzet van opsporingsberichtgeving kan er aldus toe leiden dat het OM ook later in de strafrechtelijke procedure de 'verantwoordelijkheid' heeft het publiek verder te informeren over het verloop van het strafvorderlijk onderzoek. Hoewel hierbij terughoudend moet worden omgegaan met de privacygegevens van de verdachte, kan dit wel degelijk grote gevolgen hebben voor de verdachte. De vraag is dan ook wat de verantwoordelijkheid van het $\mathrm{OM}$ is bij de afweging om al dan niet gebruik te maken van opsporingsberichtgeving - ook mede in het licht van de voorlichtingsverantwoordelijkheid - en welke afweging hij dient te maken in het licht van zijn magistratelijke positie. Deze magistratelijke positie van de officier van justitie kenmerkt zich immers door een zekere mate van objectiviteit, onpartijdigheid en onafhankelijkheid, die de officier van justitie ertoe nopen acht te slaan op de belangen van de verdachte en zorg te dragen voor een adequaat niveau van 
rechtsbescherming voor de verdachte (zie uitgebreid Crijns, 2010: 315-316; Lindeman, 2017).

De hier besproken Aanwijzing opsporingsberichtgeving geeft de kaders aan voor de inzet van opsporingsberichtgeving en erkent de moeilijk te beheersen informatiestromen door internet. De afgelopen jaren bleek verschillende keren dat de opsporingsberichtgeving inderdaad onbeheersbaar was; zo werden beelden uit een regionaal opsporingsprogramma gekopieerd en geplaatst op andere websites (zoals Dumpert). In een aantal zaken heeft deze massale media-aandacht geleid tot gevolgen voor de strafvorderlijke procedure tegen de verdachte. We lichten deze drie incidenten toe op basis van publiek toegankelijke berichtgeving. Deze drie zaken illustreren de problemen die verband houden met de beheersbaarheid van de inzet van opsporingsberichtgeving in een gedigitaliseerde samenleving.

\section{Massale aandacht door opsporingsberichtgeving bij drie incidenten}

\subsection{Gestolen portemonnee: zelfmoord na verschijnen beelden op Dumpert}

Op 23 november 2016 vergeet een 78-jarige vrouw bij de kassa in een winkel in Oldenzaal haar portemonnee mee te nemen. Een andere klant na haar steelt de portemonnee. De politie van Oost-Nederland probeert deze vrouw op te sporen. De camerabeelden laten zij zien aan het winkelpersoneel en aan het hele politieteam, ze wordt niet herkend. De camerabeelden worden getoond op donderdagavond 12 januari in het regionale opsporingsprogramma Onder de Loep van RTV Oost. Op de beelden is de vrouw goed te zien. Zij, een vrouw van 68, heeft zichzelf herkend en meteen gebeld met de politie. De politie meldt in een bericht van vrijdagochtend 13 januari dat zij haar over de diefstal nog nader zal verhoren. In het bericht wordt ook gezegd dat de bewakingsbeelden meteen uit de uitzending van het opsporingsprogramma en van het speciale YouTube-kanaal/Facebooksite van Onder de Loep zijn gehaald. RTV-Oost zegt dat dit 'zeker binnen twee uur' gebeurd is. Maar het televisiefragment met daarin de camerabeelden zijn ondertussen al op de website Dumpert verschenen, met bijschrift 'Hee dikke kuttrol!'. Het fragment wordt veelvuldig bekeken en gedeeld. In de commentaren die vooral de avond van de uitzending en de dag erna geplaatst worden, wordt grof gescholden. De vrouw pleegt zelfmoord.

Eind januari verschijnen daarover diverse berichten in lokale en nationale (nieuws)media. Ook televisieprogramma's gaan in op de zaak. Daarbij worden verschillende professionals en deskundigen aan het woord gelaten. Dumpert maakt de mensen in beeld minder herkenbaar door te blurren. Het incident leidt tot diverse berichtgeving in (nieuws)media, waarbij opiniemakers, professionals en deskundigen aan het woord komen.

\subsection{Mishandeling in Eindhoven: de kopschopperszaak}

Een 22-jarige jongeman wordt 4 januari 2013 in Eindhoven door een aantal anderen in elkaar geslagen en tegen zijn hoofd geschopt. Hij wordt bewusteloos achtergelaten. De (bewegende) camerabeelden worden op maandagavond 21 januari integraal getoond tijdens een uitzending van het regionale opsporingsprogramma 
Bureau Brabant. De beelden worden diezelfde avond geplaatst op de website GeenStijl met de kop 'VIDEO. Teringtiefustuigh sloopt jongen, 8 vs 1' samen met de dringende oproep ze te zoeken. ${ }^{3}$ Op andere websites en sociale media wordt massaal gereageerd en het filmpje wordt breed verspreid met de oproep het verder te verspreiden. Op 23 januari wordt een groepsfoto geplaatst op GeenStijl en andere media en zes namen van de jongens worden voluit gepubliceerd. Nieuwsmedia besteden aandacht aan de zaak. Gedurende de dagen erna melden verschillende jongens zich. De persofficier roept via Omroep Brabant op om niet langer beelden of gegevens van de verdachten via internet te verspreiden. Hierna melden andere jongens zich, zij zijn woonachtig in Turnhout in België. Op internet is ondertussen een 'heksenjacht' gaande, aldus de burgemeester van Turnhout in nieuwsberichten (zie Wijkhuijs \& De Vries, 2014). Er volgen rechtszaken waarbij de rechter zich ook uitspreekt over de inzet van opsporingsberichtgeving.

\subsection{Fatale overval op juwelier Stratmann}

Op 25 april 2012 rond 12:30 uur wordt juwelier Stratmann in zijn juwelierszaak overvallen. Stratmann verzet zich en wordt neergeschoten, hij overlijdt diezelfde middag nog. Op 27 april 2012 worden (bewegende) beelden van de twee overvallers uitgezonden als opsporingsbericht op Omroep West en in diverse andere tvprogramma's. De beelden worden onder andere op de website van GeenStijl geplaatst met de kop 'Gezocht. Haagse Juwelierkillers'. Ook nieuwsmedia gaan in op de zaak. De hoofdofficier van justitie in Den Haag looft een beloning uit van $€ 15.000$. De namen van de twee 19-jarigen zijn snel bekend, maar de verdachten zijn onvindbaar. Op dinsdag 1 mei worden ook de volledige namen, foto's en gegevens van de verdachten vrijgegeven (Openbaar Ministerie, 2014). Die avond wordt deze informatie in Opsporing Verzocht gepresenteerd, in diverse televisienieuwsprogramma's en op websites en sociale media gedeeld. Beide overvallers worden aangehouden. Ook nu volgen rechtszaken, waarbij de inzet van opsporingsberichtgeving ter sprake komt.

\section{$4 \quad$ Digitalisering en opsporingsberichtgeving}

Dat digitalisering grote invloed heeft gehad op de inzet van opsporingsberichtgeving, wordt geillustreerd door de hierboven beschreven incidenten en de daarmee samenhangende maatschappelijke reacties en juridische consequenties. De incidenten leggen ook bepaalde problemen bloot van deze ontwikkeling, die raken aan de kern van de veranderingen die digitalisering met zich mee heeft gebracht voor opsporingsberichtgeving. Aan deze incidenten ontlenen we de volgende vijf kenmerken van (opsporings)berichtgeving in een gedigitaliseerde samenleving. De eerste drie kenmerken hebben vooral betrekking op het medium, waar ook de huidige Aanwijzing naar verwijst in het kader van een zorgvuldige afweging over de keuze daarvoor. Overigens werd in de vervallen Aanwijzing nog expliciet jonge. 
onderscheid gemaakt tussen lokale, nationale en internationale opsporingsberichtgeving. Ook werden diverse vormen van media benoemd. In de huidige Aanwijzing is dit verdwenen en wordt alleen nog over 'medium' en 'media' gesproken. ${ }^{4}$ Opsporingsberichtgeving in de huidige tijd 'noopt tot een zorgvuldige afweging over de keuze voor de tekst, het eventuele beeldmateriaal en het medium', aldus de Aanwijzing zelf. Bij die zorgvuldige afweging zou het OM zich rekenschap moeten geven van onderstaande kenmerken.

\subsection{Traditionele en nieuwe media vloeien in elkaar over}

Een eerste kenmerk van opsporingsberichtgeving in een gedigitaliseerde samenleving is dat geen onderscheid gemaakt kan worden tussen traditionele en nieuwe (of sociale) media. Vanderveen en Oerlemans (2017) concluderen op basis van in 2016 afgenomen interviews met (pers)officieren dat sommige van hen nog vasthouden aan een traditioneel verschil tussen klassieke en nieuwe (sociale) media, zoals de Aanwijzing destijds ook deed.

Oude kanalen als de televisie, de krant en de radio als bronnen van nieuws zijn aangevuld met nieuwe kanalen. Zo is de krant altijd en overal te lezen op de bijbehorende website. Radio- en televisie-uitzendingen kunnen beluisterd en bekeken worden wanneer men wil (Wennekers \& De Haan, 2017). Traditionele en klassieke media vloeien over in sociale media, zij zijn met elkaar verweven en staan in voortdurende wisselwerking. Berichten op sociale mediaplatforms worden opgepakt door traditionele nieuwsmedia (Bayerl \& Stoynov, 2016).

Deze traditionele media zijn zelf ook actief op sociale media en op websites en communiceren middels twitterberichten, posts op Facebook, newsfeeds en blogs. De drie incidenten en het voorbeeld waarmee dit stuk begon, laten ook zien dat de diverse soorten media elkaar informeren, attenderen en complementeren (Johannink, Gorisson \& Van As, 2013).

\subsection{Regionaal en lokaal kan viraal}

Naast het televisieprogramma Opsporing Verzocht kent Nederland diverse opsporingsprogramma's op regionale omroepen, zoals Bureau Rijnmond (RTV Rijnmond) of Team West (Omroep West). De regionale opsporingsprogramma's zijn vergelijkbaar met Opsporing Verzocht, maar beperken zich tot zaken uit de eigen regio (Meijer et al., 2013; Van Erp, 2011). Zoals geïllustreerd wordt door de zaak van de gestolen portemonnee en de zogenoemde Kopschopperszaak, waarbij bewegende beelden bij de regionale opsporingsprogramma's Onder de Loep respectievelijk Bureau Brabant werden getoond, kan regionale berichtgeving voor landelijke ophef zorgen. De regionale opsporingsprogramma's (en hun websites) laten verhoudingsgewijs vaker dan het landelijke Opsporing Verzocht beelden van (kleine) winkeldiefstallen en vernielingen in de openbare ruimte zien (Van Erp, 2011).

4 De Aanwijzing gebruikt de term media 'in de ruimst mogelijke betekenis en omvat alle denkbare communicatiemiddelen, waaronder beeld- en geluidsdragers, geschreven en gedrukte berichtgeving'. 
Uit het onderzoek van Vanderveen en Oerlemans (2017) blijkt dat officieren van justitie een duidelijk onderscheid maken tussen de verschillende soorten media die zij kunnen inzetten voor opsporingsberichtgeving, conform de destijds geldende Aanwijzing. Hierbij geldt voor de meesten - zoals overigens ook werd onderstreept in de nu vervallen Aanwijzing - dat regionale en lokale verspreiding van beelden als een minder zwaar middel wordt gezien dan landelijke verspreiding. Deze mening wordt evenwel niet door alle respondenten gedeeld; terecht merkt een officier van justitie op dat door het internet geen onderscheid meer te maken is tussen regionale en landelijke verspreiding.

Hoewel in de huidige Aanwijzing gesproken wordt over media in de ruimst mogelijke betekenis en de Aanwijzing zelf geen onderscheid meer maakt tussen regionale of nationale opsporingsberichtgeving, blijkt dit in de praktijk nog wel een belangrijk referentiepunt. Op de website met een overzicht van de opsporingsprogramma's worden de huidige twee landelijke programma's als eerste gepresenteerd. Daaronder staat de lijst met regionale opsporingsprogramma's. ${ }^{5}$

\subsection{Analoog kan digitaal en dus viraal}

Het is een illusie te denken dat analoge opsporingsberichtgeving beheersbaar is. Het onderscheid dat de vervallen Aanwijzing maakte tussen inzet van analoge opsporingsberichtgeving en opsporingsberichtgeving via sociale media was problematisch. In Vanderveen en Oerlemans (2017) maakt een officier van justitie duidelijk onderscheid tussen billboards en stoepborden ('ouderwets', p. 338). Deze zijn minder vergaand volgens de respondent dan het verspreiden van beelden via internet of de landelijke uitzending van Opsporing Verzocht.

Een van de oudste manieren om burgers in te schakelen bij de opsporing zijn inderdaad aanplakbiljetten (Meijer et al., 2013). Met de posters laat de politie weten welke personen gezocht worden. Naast papieren aanplakbiljetten worden ook stoepborden, flyers en digitale billboards gebruikt. Daar kunnen makkelijk, bijvoorbeeld met een smartphone, foto's van worden gemaakt die vervolgens weer gedeeld kunnen worden op sociale media en eventueel viral gaan. De politie maakt zelf ook gebruik van deze mogelijkheid (zie foto 1 ).

\subsection{Informatie op internet permanent zichtbaar}

Meijer et al. (2012, p. 191) stellen dat de brede verspreiding van persoonsgegevens via sociale media vergelijkbaar is met de verspreiding via traditionele massamedia (bijv. televisie), maar wijzen op een belangrijk verschil: informatie die eenmaal op internet staat, is niet of moeilijk te verwijderen of aan te passen. De (mogelijk incorrecte) informatie blijft altijd ergens vindbaar (zie Solove, 2007; Jacobs, 2005). Ook de Aanwijzing wijst op het 'permanente digitale geheugen' en de benodigde zorgvuldige afweging.

Nog steeds zijn allerlei berichten en beelden van de vrouw die een portemonnee steelt (hoewel nu op Dumpert geblurd) te vinden, evenals de foto's en namen van (vermeende) verdachten dan wel daders in de Kopschopperszaak en de overval op 


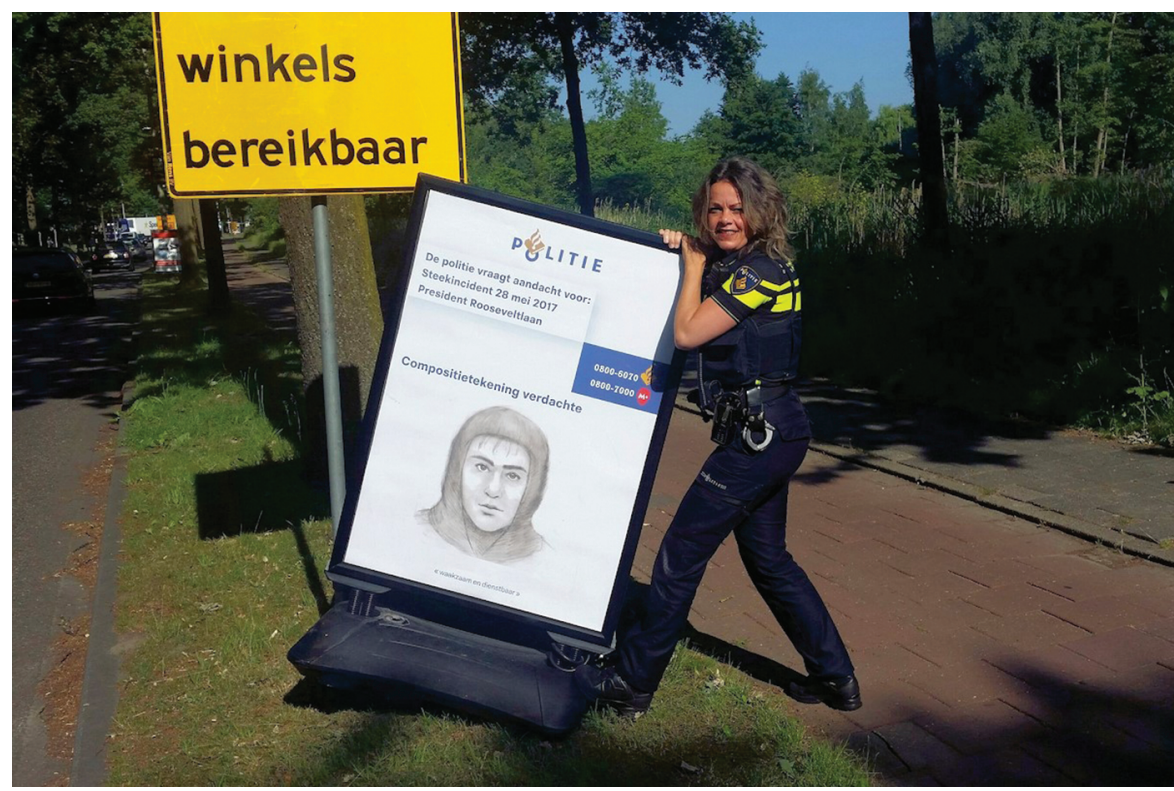

Foto 1

Stoepbord van verdachte, geplaatst 14 juni 2017 door agente op haar twitteraccount (twitter.com/brigadierstipwa) met een oproep voor informatie en getuigen. De foto wordt ook geplaatst op www.deweblogvanhelmond.nl.

juwelier Stratmann. Internet maakt dat 'information that was once scattered, forgettable, and localized is becoming permanent and searchable' (Solove, 2007: 4). Deze 'eeuwigheidswaarde' van informatie vraagt mogelijk andere afwegingen van het OM.

\subsection{Burgers consumeren niet alleen, maar produceren ook}

De Aanwijzing wijst op de mogelijke verdere verspreiding door derden van een opsporingsbericht via internet of sociale media met de toevoeging van kwalificaties aan het primair verspreide beeld. Naast het 'zenden' van opsporingsberichtgeving kunnen burgers daarop reageren en de berichten reproduceren, al dan niet becommentarieerd of aangepast.

Van Erp (2011) wijst erop dat daarbij een grote variëteit aan interpretaties ontstaat. Burgers zijn daarbij niet alleen maar aangever van informatie, maar kunnen hun eigen interpretatie geven aan de opsporing. Het ontelbare aantal nationale en internationale nieuwssites, blogs, online discussieplatforms kenmerken zich door interactiviteit en user-generated content (RMO, 2011). Dankzij de netwerkstructuur is alles met elkaar verbonden en kan informatie makkelijk gekopieerd, becommentarieerd en verder doorgegeven worden (Vasterman, 2010). Het doorlinken maakt een 'snelle, virusachtige verspreiding' mogelijk (Vasterman, 2010: 123). Door de grote mate van onderlinge connectiviteit tussen mensen kunnen 
online firestorms ontstaan, plotselinge golven van grote hoeveelheden negatieve, intens verontwaardigde reacties (Pfeffer, Zorbach \& Carley, 2014).

Ook bij de drie beschreven incidenten lijkt dit het geval. Burgers hebben de opsporingsberichten in grote mate gereproduceerd en soms het bericht ook getransformeerd door bijvoorbeeld informatie toe te voegen. Daardoor kunnen burgers veel meer autonomie verkrijgen: niet alleen meepraten, maar meedoen (Van Erp, 2011).

Door deze vijf kenmerken of ontwikkelingen kan opsporingsberichtgeving van een relatief minder ernstig delict grootschalige en landelijke aandacht krijgen. Opiniestukken in kranten en ook de deskundigen die aan het woord komen in (nieuws)media nadat de zelfmoord van de vrouw die de portemonnee had gestolen bekend werd, lijken op één lijn te zitten: het OM had andere keuzes moeten maken. Van Erp bijvoorbeeld is in interviews naar aanleiding van dit incident kritisch over de beslissing van het $\mathrm{OM}$ om deze beelden uit te zenden en noemt deze niet proportioneel. Het OM stelt in de nieuwsberichten dat conform de Aanwijzing het $\mathrm{OM}$ wel degelijk rekening heeft gehouden met de verschillende in het geding zijnde belangen, wijst op de verantwoordelijkheid van sites als Dumpert en geeft ook aan dat de samenleving zelf verwachtingen heeft die juist stroken met de beslissing om beelden van de diefstal te publiceren. Officier van justitie Ernst Pols:

'Hoe vaak krijgen wij niet het verwijt: winkeldiefstallen en vernielingen zorgen voor honderden miljoenen aan schade - jullie hebben de beelden, waarom zetten jullie ze niet online? Moeten we tegen al die winkeliers en slachtoffers zeggen: joh, rot voor je, maar wees maar lekker slachtoffer, de privacy is belangrijker?' (in: Efting, 2017)

De reacties op het Facebookbericht om de gestolen motor op te sporen die we bespraken in de introductie van dit stuk lijken dit te onderschrijven. En ook officier Diederik Greive wijst in het interview in De Telegraaf op het maatschappelijke draagvlak voor het delen van opsporingsberichtgeving. De maatschappij wil graag zien dat het $\mathrm{OM}$ de jacht op criminelen serieus neemt en de rol van de burger wordt daarbij als onmisbaar beschouwd: 'Ik weet zeker dat dit gaat zorgen voor meer vertrouwen' (in: Van Wely, 2017). Bovendien lijkt de burger zich maar weinig druk te maken om het recht op privacy van de verdachte (Stols, 2017).

De belangenafwegingen van het OM worden mede genormeerd door de rechterlijke toets. Hoewel deze rechterlijke toets van belang is voor de belangenafweging van het $\mathrm{OM}$, moet worden opgemerkt dat de inzet van opsporingsberichtgeving zelden leidt tot rechtsgevolgen in de strafzaak tegen de verdachte. Aan de hand van de Kopschopperszaak, die als enige van de genoemde incidenten door de Hoge Raad is beoordeeld, gaan wij hierna in op de strafprocessuele gevolgen. 


\section{Strafprocessuele gevolgen van de onrechtmatige inzet van opsporingsberichtgeving}

Zoals gezegd kan de inzet van opsporingsberichtgeving gevolgen hebben voor de strafzaak tegen de verdachte. Dit opsporingsmiddel maakt immers inbreuk op het recht op privacy van de verdachte en het is mogelijk dat deze gevolgen dermate ernstig zijn, dat de inzet ervan als onrechtmatig dient te worden aangemerkt. Wanneer de rechter achteraf vaststelt dat de inzet van opsporingsberichtgeving niet heeft voldaan aan de eisen van de wet (in dit geval de Aanwijzing) - bijvoorbeeld omdat niet is voldaan aan de beginselen van proportionaliteit en subsidiariteit - dan kan hij daar rechtsgevolgen aan verbinden in de strafprocedure tegen de verdachte (in de regel komt dat neer op een matiging van de op te leggen straf op grond van art. 359a Sv of art. 8 EVRM). Een beroep op de onrechtmatigheid van de inzet van dit soort berichtgeving komt in de rechtspraak met enige regelmaat voor, maar wordt zelden als onrechtmatig beoordeeld door de rechter, laat staan dat het tot een strafprocessueel gevolg leidt. ${ }^{6}$ Immers, wil een normoverschrijding in aanmerking komen voor sanctionering door middel van strafvermindering conform artikel 359a Sv, dan dient de verdachte daadwerkelijk nadeel te hebben ondervonden in de vorm van schending van zijn individuele rechten én dat nadeel moet geschikt zijn voor compensatie door strafvermindering. Dit rechtgevolg heeft dus een compensatoir karakter, het beoogt de verdachte compensatie te bieden voor de schending van zijn rechten. ${ }^{7}$

In de eerder beschreven Kopschopperszaak werd de inzet van opsporingsberichtgeving door de rechter als onrechtmatig bevonden, wat uitzonderlijk is. Tijdens het onderzoek ter terechtzitting bij het hof erkende het OM dat het had kunnen volstaan met foto's van de camerabeelden, zogenoemde stills. De inbreuk op de rechten van de verdachte zou dan minder belastend zijn geweest. Het OM was echter van oordeel dat in het licht van de ernst van het geweldsincident het inzetten van deze 'troefkaart, het middel dat het grootste bereik heeft', geoorloofd was. Het hof oordeelde dat dit handelen een ernstige schending van de privacy van de verdachte opleverde, daar het OM een minder ingrijpend middel had kunnen inzetten (subsidiariteit), en paste conform artikel 359a Sv strafvermindering toe. ${ }^{8}$ Het OM ging in cassatie. Hoewel de Hoge Raad de strafvermindering in stand laat, stelt hij wel dat deze beoordeling van het hof geplaatst had moeten worden in de sleutel van artikel 8 EVRM en de strafmaatbeslissing (en niet in het kader van art. 359a Sv). ${ }^{9}$ De Hoge Raad somt ook een aantal factoren op die belangrijk zijn voor de belangenafweging bij de inzet van opsporingsberichtgeving en de in dat kader van belang zijnde eisen van proportionaliteit en subsidiariteit. Deze factoren zijn bijvoorbeeld het publieke dan wel private karakter van de plaats die op het beeldmateriaal waarneembaar is waar of van de situatie waarin

6 zie Rb. Rotterdam 12 november 2012, ECLI:NL:RBROT:2012:BY3828; Hof Den Haag 20 november 2012, ECLI:NL:GHSGR:2012:BY3551; Hof Den Haag 19 december 2012, ECLI:NL:GHSGR: 2012:BY6574; Rb. Leeuwarden 12 oktober 2012, ECLI:NL:RBLEE:2012:BY2634.

7 HR 30 maart 2004, ECLI:NL:HR:2004:AM2533.

8 Hof Den Bosch 11 december 2013, ECLI:NL:GHSHE:2013:5955.

9 ECLI:NL:HR:2015:3024. 
de betrokkene zich bevindt, de persoon van de betrokkene (waaronder diens leeftijd, bijzondere kwetsbaarheid, publieke bekendheid), de mate van herkenbaarheid, het doel waarmee het beeldmateriaal is vergaard en geopenbaard, waarbij aan de orde kan komen of het gaat om opsporing of identificatie van verdachten van (ernstige) strafbare feiten en of voorzienbaar is dat het beeldmateriaal wordt gebruikt op een wijze die verder gaat dan hetgeen redelijkerwijze nodig is voor het te bereiken doel en de wijze van vergaring en openbaarmaking van het beeldmateriaal.

De Hoge Raad heeft geen inzicht gegeven in de achterliggende redenen van het afdoen van dergelijke inbreuken op de privacy van de verdachte langs de weg van artikel 8 EVRM (en de strafmaatbeslissing) in plaats van in het kader van artikel 359a Sv, daarover kunnen we alleen speculeren. Wel past dit arrest in de lijn van jurisprudentie waarin steeds meer normschendingen van politie en justitie buiten het kader van artikel 359a Sv worden gehouden. Dit lijkt mede ingegeven vanuit de terughoudendheid van de rechter om een uitvoerige controle op het handelen van politie en justitie uit te oefenen. Betoogd kan echter ook worden dat de inzet van de opsporingsberichtgeving en de informatieverstrekking op zichzelf niet onrechtmatig is en in die zin dan ook geen vormverzuim oplevert. Stevens (2010: 662) stelt dat het probleem juist bestaat uit hetgeen zich voordoet nadat de zaak in de publiciteit is gebracht. Dit verklaart dan ook waarom de juridische afdoening niet wordt ingevuld door artikel 359a Sv, maar aan de hand van artikel 8 EVRM (Moerman, 2016: 282).

In het licht van de verschillende incidenten die zich inmiddels hebben voorgedaan na het inzetten van opsporingsberichtgeving, is het de vraag of de kern van het probleem daadwerkelijk in de rechtsgevolgen van deze opsporingsmethode zit. De strafrechter ziet niet snel problemen met de inzet van opsporingsberichtgeving en is zelfs wanneer hij de inzet van dit middel onrechtmatig acht niet bepaald genegen hier rechtsgevolgen aan te verbinden. Illustratief in dit kader is een vonnis van de Rechtbank Den Haag waarin de rechtbank overweegt dat de nog lang na-ijlende media-aandacht als gevolg van het uitvaardigen van opsporingsberichtgeving weliswaar te betreuren is vanuit het oogpunt van resocialisatie van de verdachte, maar dat verdachte, 'een kind van zijn tijd', erop bedacht had kunnen zijn dat er beelden zouden zijn van het misdrijf waar hij zich schuldig aan had gemaakt (in casu een overval op een juwelier). ${ }^{10}$ Een overweging waar dezelfde afweging in weerklinkt als het eerder aangehaalde citaat van officier van justitie Greive. Het OM komt dan ook grote beslissingsvrijheid toe bij de (normering van de) inzet van opsporingsberichtgeving. Uit de nieuwe aanwijzing en de uitlatingen van officier van justitie Diederik Greive in het interview in De Telegraaf lijkt het OM zich vooral te laten leiden door de wens van de maatschappij dienstig te zijn aan criminaliteitsbestrijding en bij de afweging van belangen lijken de belangen van slachtoffers vooropgesteld te worden. De vraag is echter of de hiervoor genoemde problemen die kleven aan het gebruik van opsporingsberichtgeving niet meebrengen dat het OM terughoudender zou moeten omgaan met de inzet van opsporingsberichtgeving en bij deze afwegingen explicieter zou moeten 
reflecteren op de typische kenmerken van opsporingsberichtgeving in een gedigitaliseerde samenleving.

\section{Conclusie}

In een gedigitaliseerde samenleving is de bestrijding van criminaliteit niet altijd exclusief voorbehouden aan het OM. De mondige burger kan zich door middel van het internet (en sociale media en apps) steeds makkelijker bemoeien met de opsporing. De wetgever geeft er zoals gezegd blijk van welwillend te staan tegenover verdere burgerparticipatie in de opsporing. In het eerdergenoemde wetsvoorstel 'publicatie camerabeelden verdachten diefstal of vernieling' wordt mogelijk gemaakt dat eenieder camerabeelden van diefstal en vernieling deelt op het internet. Kennelijk vanuit de hoop dat meer burgerparticipatie in de opsporing bijdraagt aan een groter vertrouwen van de maatschappij in politie en $\mathrm{OM}$. Nu duidelijk is dat de gevolgen van opsporingsberichtgeving door het $\mathrm{OM}$ zélf al tamelijk onvoorzienbaar en oncontroleerbaar zijn en bovendien kunnen nopen tot het nader informeren van de burger over het verloop van een strafzaak met de daarbij horende aanhoudende media-aandacht, is het de vraag of de politiek er goed aan doet om op deze manier de opsporing te populariseren. Hierbij gaat het niet enkel om het feit dat het ongebreidelde delen van foto's van vermeende criminelen de kans op vergissingen in (herkenning van) personen en eigenrichting (digilantism) vergroot, er is ook een rechtsstatelijk probleem. Het bestrijden van criminaliteit dreigt gepaard te gaan met de verdere uitholling van belangrijke grondrechten. Een kwestie die het OM gezien zijn magistratelijke positie ook aangaat.

De kenmerken van het huidige medialandschap vragen om een bredere maatschappelijke discussie over het gebruik van opsporingsberichtgeving. Hiertoe zou bijvoorbeeld een privacy impact assessment als basis kunnen dienen, waardoor op meer systematische wijze gereflecteerd wordt op het belang van privacy in opsporing (zie ook Koops et al., 2016). Vanuit de maatschappij is er forse druk op politie en $\mathrm{OM}$ het opsporingsbelang te laten prevaleren boven andere (meer rechtsstatelijke) belangen. Er zijn voldoende signalen dat de maatschappelijke gevolgen van opsporingsberichtgeving zeer verstrekkend kunnen zijn voor betrokkenen, terwijl de effecten op de lange termijn van dit opsporingsmiddel - het vertrouwen in de strafrechtspleging, maar ook de gevolgen voor het individu - nog onduidelijk zijn. Het loslaten van verschillende onderscheidingen - tussen regionale en landelijke, en analoge en digitale media - in de nieuwe Aanwijzing kan in dit licht een positieve ontwikkeling zijn, daar deze onderscheidingen veelal gekunsteld voorkomen. De kenmerken van de digitale samenleving maken dergelijke onderscheidingen immers diffuus. Bij het afwegen van belangen zou het $\mathrm{OM}$ in ieder geval expliciet rekening moeten houden met de kenmerken van het veranderde medialandschap. De inzet van opsporingsberichtgeving in een gedigitaliseerde samenleving vraagt om reflectie en terughoudendheid. 


\section{Literatuur}

Aarsen, A. van (2017) Beelden van motordief, 'maar politie doet niks'. Leidsch Dagblad, 2 augustus 2017. Laatst geraadpleegd 11 mei 2018 via www.leidschdagblad.nl/leiden-en -regio/beelden-van-motordief-maar-politie-doet-niks .

Baan, P. et al. (1971) Verslag van de werkgroep opsporingsberichtgeving per televisie. Den Haag: Strafbureau Voorlichting Ministerie van Justitie.

Bayerl, P.S. \& L. Stoynov (2016) Revenge by photoshop: Memefying police acts in the public dialogue about injustice. New Media \& Society, 18(6), 1006-1026.

Efting, M. (2017) Zelfmoord na beelden diefstal: te zwaar middel ingezet?. de Volkskrant, 30 januari 2017, 14.

Erp, J.G. van (2011) 'Boeven vangen' via internet. Beelden over criminaliteit in opsporingsberichtgeving. Tijdschrift over Cultuur en Criminaliteit, 1(0), 51-70.

Erp, J.G. van, F. van Gastel \& H.D. Webbink (2012) Opsporing verzocht. Een quasi-experimentele studie naar de bijdrage van het programma Opsporing Verzocht aan de oplossing van delicten. Apeldoorn: Politie \& Wetenschap.

Jacobs, J.B. (2015) The eternal criminal record. Cambridge, MA: Harvard University Press.

Johannink, R.H., I. Gorissen \& N.K. van As (2013) Sociale media: factor van invloed op onrustsituaties?. Amsterdam: Reed Business/Politie \& Wetenschap.

Kalkman, N. (2017) Privacywet dekt motordief. De Telegraaf, 3 augustus 2017. Laatst geraadpleegd 11 mei 2018 via www.telegraaf.nl/nieuws/287086/privacywet-dektmotordief.

Klomp, C. (2017) Ook slachtoffers en getuigen van misdrijven herkenbaar in beeld. Algemeen Dagblad, 20 november 2017. Laatst geraadpleegd 6 april via www.ad.nl/ binnenland/ook-slachtoffers-en-getuigen-van-misdrijven-herkenbaar-inbeeld af7d5157 .

Koops, B., A. Roosendaal, E. Kost, M. van Lieshout \& E. Oldhoff (2016) Privacy Impact Assessment Wet op de inlichtingen- en veiligheidsdiensten 20XX. Delft: TNO. Laatst geraadpleegd 6 april via https://zoek.officielebekendmakingen.nl/blg-742355.

Kop, N. (2013) Burgerparticipatie; hoe houdt de politie de regie?. Tijdschrift voor de Politie, 75(6), 18-19.

Kop, N. (2016) Burgerparticipatie in de opsporing: kunnen we een treetje hoger?. Tijdschrift voor de Politie, 78(7), 27-30.

Laarhoven, K. van (2018) Zoek mee naar vermiste, maar loop de politie niet in de weg. NRC, 16 januari 2018. Laatst geraadpleegd 11 april via www.nrc.nl/nieuws/2018/01/ 16/zoek-mee-naar-vermiste-maar-loop-de-politie-niet-in-weg-a1588538.

Lent, L. van (2008) Externe openbaarheid in het strafproces (diss. Utrecht). Den Haag: Boom Juridische uitgevers.

Meijer, A.J. (2014) New media and the coproduction of safety. The American Review of Public Administration, 44(1), 17-34.

Meijer, A.J., S.G. Grimmelikhuijsen, D. Fictorie, M. Thaens \& P. Siep (2013) Politie en sociale media. Van hype naar onderbouwde keuzen. Apeldoorn: Politie en Wetenschap.

Ministerie van Justitie en Veiligheid (2015) Wetsvoorstel publicatie door particulieren van camerabeelden van diefstal of vernieling. Laatst geraadpleegd 14 maart via www. internetconsultatie.nl/wetsvoorstelcamerabeelden/details.

Moerman, E.M. (2016) Inburgeren in de opsporing Over de juridische positie van de burger in de opsporing van strafbare feiten (diss. EUR). Enschede: Gildeprint.

Nhan, J., L. Huey \& R. Broll (2017) Digilantism: An analysis of crowdsourcing and the Boston marathon bombings. The British Journal of Criminology, 57(2), 341-361. 
Openbaar Ministerie (2014) Fatale overval op juwelier; Officier van justitie Janine Berton over zaak-Stratmann. In Jaarbericht 2013, 38-40.

Openbaar Ministerie (2017) Aanwijzing opsporingsberichtgeving verruimd. Persbericht 20 november 2017, laatst geraadpleegd 19 maart via www.om.nl/@101094/aanwijzingverruimd.

Pfeffer, J., T. Zorbach \& K.M. Carley (2014) Understanding online firestorms: Negative word-of-mouth dynamics in social media networks. Journal of Marketing Communications, 20(1-2), 117-128.

Raad voor Maatschappelijke Ontwikkeling (2011) De nieuwe regels van het spel: Internet en publiek debat. Den Haag: RMO.

Solove, D. (2007) The future of reputation, gossip, rumor and privacy on the internet. New Haven: Yale University Press.

Stevens, L. (2010) Strafzaken in het nieuws. Over ontsporende media en de verantwoordelijkheid van het Openbaar Ministerie. Nederlands Juristenblad, 85(11), 660-665.

Stols, M. (2017) Uitslag Stelling: Boef in beeld zetten helpt, Wat U Zegt. De Telegraaf 21 november 2017. Laatst geraadpleegd 13 maart 2018 via www.telegraaf.nl/nieuws/ 1278923/uitslag-stelling-boef-in-beeld-zetten-helpt .

TNO (2018) Doe-het-zelf-opsporing met de Sherlock-app. TNO webartikel, 15 januari 2018. Laatst geraadpleegd 11 april via https://time.tno.nl/nl/artikelen/doe-het-zelfopsporing-met-de-sherlock-app.

Vanderveen, G.N.G. \& M. Oerlemans (2017) Magistratelijke afwegingen: Officieren van justitie over hun afwegingen bij het al dan niet verspreiden van beelden van gewelddadige incidenten. In R.H.J.M. Staring, R. van Swaaningen \& C.G. van Wingerde (red.), Over de muren van stilzwijgen. Liber amicorum Henk van de Bunt (p. 329-342). Den Haag: Boom Criminologie.

Vasterman, P.L. (2010) De digitale schandpaal. Tijdschrift voor Communicatiewetenschap, 38(2), 118-138.

Webbink, D., J. van Erp \& F. van Gastel (2017) The effect of media exposure of suspects on solving crime. The Economic Journal, 127(600), 547-570.

Wely, M. van (2017) Burger ingezet bij opsporing; hoofdofficier Diederik Greive perkt het recht op privacy van criminelen in. De Telegraaf, maandag 20 november 2017, T2-T3.

Wennekers, A. \& J. de Haan (2017) Nederlanders en nieuws. Den Haag: Sociaal Cultureel Planbureau.

Wijkhuis, V. \& A. de Vries (2014) De kopschoppers van Eindhoven. In M. van Duin \& V. Wijkhuis (red.), Lessen uit crises en mini-crises (pp. 43-57). Den Haag: Boom Lemma Uitgevers. 